\title{
ANALYSIS CONCENTRATION OF SURFACTANT ANIONIC AND THE RELATION WITH DIATOM ABUNDANCE IN BUNGUS WATER, PADANG WEST SUMATERA
}

\author{
Rukiana Audi Putri $^{{ }^{*}}$, Syahril Nedi ${ }^{2}$ Irvina Nurrachmi ${ }^{2}$ \\ ${ }^{1}$ Student of The Faculty of Fisheries and Marine Science University of Riau, Pekanbaru \\ ${ }^{2}$ Lecturer at The Faculty of Fisheries and Marine Science University of Riau, Pekanbaru \\ * fauzir06@gmail.com
}

\begin{abstract}
This research aims to analyze surfactant anionic concentration and diatom abundance that has been implemented at May 2018 in Bungus rivers, Padang. This Research were conducted in survey method, four station were eshtablished with three replication of each sampling station. Analysis of surfactant anionic and diatom content was done at Chemistry Oceanography Laboratory and diatom identification was performed at Biology Oceanography Laboratory. The results showed that surfactant content in the waters ranged from $0,309-0,773$ ppm and diatom abundance based on laboratory test on ranged 40,7407-81,4815 Ind/l. The correlation of surfactant and diatom content in waters by using linear regression $\mathrm{y}=\mathrm{Y}=$ $94.56-66.8 x$ with correlation coefficient $r=0,809$ and correlation water quality parameters with diatom abundance by using multiple linear regression $Y=787,189-238,828_{X 1}-9,032_{X 2}-$ $6,185_{\mathrm{X} 3}+5,371_{\mathrm{X} 4}+303,081_{\mathrm{X} 5}-35,631_{\mathrm{X} 6}$ with determination regression 0,995 and correlation coefficient $r=0,997$.
\end{abstract}

Keywords: Surfactant Anionic, Diatom, Bungus Waters, Padang

\section{PENDAHULUAN}

Perairan Bungus merupakan perairan yang berada sangat dekat dengan Teluk Bayur yang merupakan salah satu pelabuhan yang utama di Pantai Barat Pulau Sumatera dan berpotensi bagi perekonomian Propinsi Sumatra Barat. Oleh karena itu pelabuhan ini selalu sibuk oleh berbagai aktifitas manusia, seperti tempat bongkar muat semen, pupuk, batubara, minyak. Setelah melakukan bongkar muat biasanya akan dilakukan pembersihan kapal yang limbahnya akan langsung dibuang ke perairan. Aktifitas masyarakat di sekitar Perairan Bungus juga sangat berpengaruh terhadap limbah di sekitar perairan tersebut. Selain itu terdapat objek wisata yang cukup ramai pengunjung yaitu pantai Nirwana dan Carolina di sepanjang perairan ini. Salah satu pencemaran yang tejadi di perairan ini adalah pencemaran oleh surfaktan dimana surfaktan merupakan bahan dasar pembuatan deterjen. Deterjen adalah pembersih sintesis yang terbuat dari bahanbahan kimia antara lain surfaktan, builder, filler dan additives. Deterjen yang digunakan pada saat ini dominan mengandung bahan aktif surfaktan anionik. Surfaktan memiliki mempunyai gugus polar yang berbeda yaitu hydrophhile (menarik air) dan hydrophobe (menarik lemak). Bahan ini berfungsi menurunkan tegangan permukaan air sehingga dapat melepaskan kotoran yang menempel pada permukaan bahan (Marga et al., 2010). Produk deterjen saat ini sudah digunakan 
oleh hampir semua masyarakat untuk berbagai keperluan seperti mencuci pakaian dan perabotan serta sebagai bahan pembersih lainnya. Surfaktan juga adalah molekul organik yang sulit larut dalam air dan menyebabkan timbulnya busa dalam perairan. Adanya buangan zat kimia yang berupa sabun (deterjen) yang berlebihan dalam air ditandai dengan timbulnya buih - buih sabun pada permukaan air (Kamiswari, 2013). Adanya busa di permukaan air dapat menghambat masuknya cahaya matahari ke perairan dan akhirnya mengganggu kelangsungan hidup biota yang ada di perairan itu. Pencemaran akibat limbah surfaktan menyebabkan timbulnya residu di hampir semua perairan seperti danau sungai, laut dan air tanah dangkal. Menurut Terangna et al, 1989 bahwa surfaktan anionik yang mengandung alkil sulfonat pada kadar 5-10 ppm bersifat racun terhadap alga. Buih yang dihasilkan oleh deterjen diperkirakan juga akan mempengaruhi difusi oksigen dari udara ke dalam air.

Diatom merupakan salah satu organisme yang biasa digunakan sebagai bioindikator lingkungan perairan. Hal ini dikarenakan diatom sangat mempengaruhi kehidupan di perairan karena memegang peranan penting sebagai sumber makanan dalam rantai makanan bagi berbagai organisme laut dan berperan dalam perpindahan karbon, nitrogen dan pospat (Siregar et al., 2008).

Diatom berfotosintesis dengan bantuan sinar matahari, sedangkan dampak pencemaran surfaktan di permukaan air dapat mengganggu proses masuknya cahaya matahari ke dalam perairan maka perlu dilakukan penelitian untuk mengetahui apa hubungan konsentrasi surfaktan dengan diatom di Perairan Bungus Padang, Sumatera Barat. Penelitian ini bertujuan menganalisis konsentrasi surfaktan anionik, menganalisis kelimpahan diatom, menganilis hubungan konsentrasi surfaktan dan diatom dan mengetahui faktor Fisika - Kimia yang dominan mempengaruhi kelimpahan diatom di Perairan Bungus Padang, Sumatera Barat.

\section{METODE PENELITIAN}

\section{Waktu dan Tempat}

Penelitian ini dilaksanakan pada bulan Mei 2018. Pengambilan sampel air dilakukan di Perairan Bungus, Padang Sumatera Barat. Analisis konsentrasi surfaktan dan diatom dilakukan di laboratorium Kimia Laut Jurusan Ilmu Kelautan dan Laboratorium Biologi Laut Fakultas Perikanan dan Kelautan Universitas Riau

\section{Metode Penelitian dan Analisis Data}

Metode yang digunakan dalam penelitian ini adalah metode survey, dimana lokasi pengambilan sampel berada di Perairan Bungus, Padang Sumatera Barat. Sampel yang telah diambil kemudian dibawa ke laboratorium untuk dianalisis konsentrasi surfaktan dan diidentifikasi jenis diatom serta dihitung jumlah kelimpahan diatom, selanjutnya dibahas secara deskriptif. Perhitungan kadar Surfaktan Anionik dihitung berdasarkan prosedur SNI (06-6989.51-2005) Kadar Surfaktan Anionik (mg/L) $=$ C x Fp

Keterangan:

C : Kadar yang didapat dari hasil pengukuran $(\mathrm{mg} / \mathrm{L})$;

Fp : Faktor pengenceran.

Sementara perhitungan kelimpahan diatom menggunakan Fachrul (2007)

Keterangan:

$$
\mathrm{N}=Z \times \frac{X}{Y} \times \frac{1}{V}
$$

$\mathrm{N}$ : Kelimpahan diatom (ind/L)

$\mathrm{Z}$ : Jumlah Individu diatom

$\mathrm{X}$ : Volume air sampel yang tersaring $(100 \mathrm{ml})$

$\mathrm{Y}$ : Volume air sampel dibawah cover glass $(0,06 \mathrm{ml})$

V : Volume air yang disaring (100 L) 
Sedangkan untuk melihat hubungan konsentrasi surfaktan anionic digunakan uji regresi sederhana dengan persamaan $\mathrm{Y}=$ $a+b x$ dan untuk melihat hubungan kualitas perairan dengan kelimpahan diatom digunakan uji regresi berganda dengan persamaan

$$
\mathrm{Y}=\mathrm{a}+\mathrm{bx_{1 }}+\mathrm{bx_{2 }}+\mathrm{bx}_{3}+b \mathrm{x}_{4}+b \mathrm{x}_{5}+b \mathrm{x}_{6}
$$

\section{HASIL DAN PEMBAHASAN} Keadaan Umum Lokasi Penelitian

Perairan Bungus memiliki panjang garis pantai 21.050 meter dan panjang perairan 5.418 meter, volume 223.255.052,2 $\mathrm{m}^{3}$, memiliki bentuk permukaan yang cenderung membulat dan luas permukaannya $1383,86 \mathrm{~m}^{2}$ berlokasi di sebelah selatan Teluk Bayur dan memiliki posisi strategis menghadap Samudera Hindia (Kusumah dan Widjarnako, 2008). Perairan ini termasuk dalam Kecamatan Bungus Teluk Kabung dan merupakan salah satu kecamatan pesisir di wilayah selatan Kota Padang. Secara astronomis kecamatan ini berada pada posisi $01^{0}$ $01 ' 21^{\prime}$ ' $-01^{\circ} 05$ '02', Lintang Selatan (LS) dan $100^{\circ} 21^{\prime} 58^{\prime \prime}-100^{\circ} 26^{\prime} 36^{\prime}$ ' Bujur Timur (BT) dan terletak di bagian barat pantai Pulau Sumatera. Kecamatan Bungus Teluk Kabung berada pada ketinggian ratarata sekitar 0-5 $\mathrm{m}$ dpl untuk daerah pesisir, dan $<850 \mathrm{~m}$ untuk daerah perbukitan. Temperatur berkisar antara $22,5^{\circ} \mathrm{C}-$ $31,5^{\circ} \mathrm{C}$ dan curah hujan $314,47 \mathrm{~mm} / \mathrm{bulan}$. Sebagian besar daerah Kecamatan ini memiliki pantai yang terjal dan curam. Dari hasil penelitian PRWLSDNH (2006) diperoleh bahwa perairan Teluk Bungus mempunyai Nilai Fomzal 0.43 berjenis tipe pasang surut campuran condong ke harian ganda (mixed semi diurnal tide) yaitu terjadi dua kali pasang dan dua kali surut dalam sehari, dengan variasi yaitu pasang terendah dan pasang tertinggi berkisar antara 1-2 meter.

\section{Parameter Kualitas Perairan}

Hasil pengukuran kualitas perairan dapat dilihat pada Tabel 1.

Tabel 1. Rata- Rata Pengukuran Parameter Perairan Bungus

\begin{tabular}{cccccc}
\hline Stasiun & Suhu $\left({ }^{\circ} \mathrm{C}\right)$ & Salinitas $(\mathrm{ppt})$ & $\mathrm{pH}$ & Kec. Arus $(\mathrm{m} / \mathrm{det})$ & Kecerahan $(\mathrm{m})$ \\
\hline 1 & 30 & 29 & 7 & 0,7 & 0,61 \\
2 & 31 & 29 & 8 & 0,7 & 0,61 \\
3 & 31 & 29 & 8 & 0,8 & 0,36 \\
4 & 30 & 28 & 7 & 0,7 & 0,36 \\
\hline
\end{tabular}

Tabel 1. Rata- Rata Pengukuran Parameter Perairan Bungus Pada Tabel 1 dapat dilihat bahwa kisaran parameter kualitas perairan setiap antar stasiun, dimana berkisar antara $30-31{ }^{\circ} \mathrm{C}$, salinitas berkisar antara 28-29 ppt, $\mathrm{pH}$ berkisar antara 7-8, kecepatan arus berkisar antara 0,7-0,8 $\mathrm{m} /$ det. Kecerahan terendah terdapat pada Stasiun 3 yaitu $0,36 \mathrm{~m}$, dan tertinggi pada Stasiun 1 dan 2 sebesar 0,61 m. Hal ini terjadi dikarenakan pada Stasiun 3 merupakan daerah dekat penduduk dimana terjadi pembuangan limbah domestik yang cukup besar sehingga membuat kecerahan pada stasiun ini paling rendah. Sementara pada Stasiun 1 merupakan daerah hutan yang sangat minim aktifitas manusia dan Stasiun 2 merupakan daerah pariwisata (Pantai Nirwana).

\section{Konsentrasi Surfaktan Anionik di Perairan Bungus}

Surfaktan Anionik merupakan salah satu parameter penting dalam pendugaan pencemaran perairan, khususnya untuk wilayah yang berbatasan langsung dengan aktivitas manusia, seperti kawasan industri, pelabuhan dan pemukiman. Konsentrasi 
surfaktan anionik yang terdapat di Perairan

dilihat pada Gambar 1.

Bungus Padang, Sumatera Barat dapat

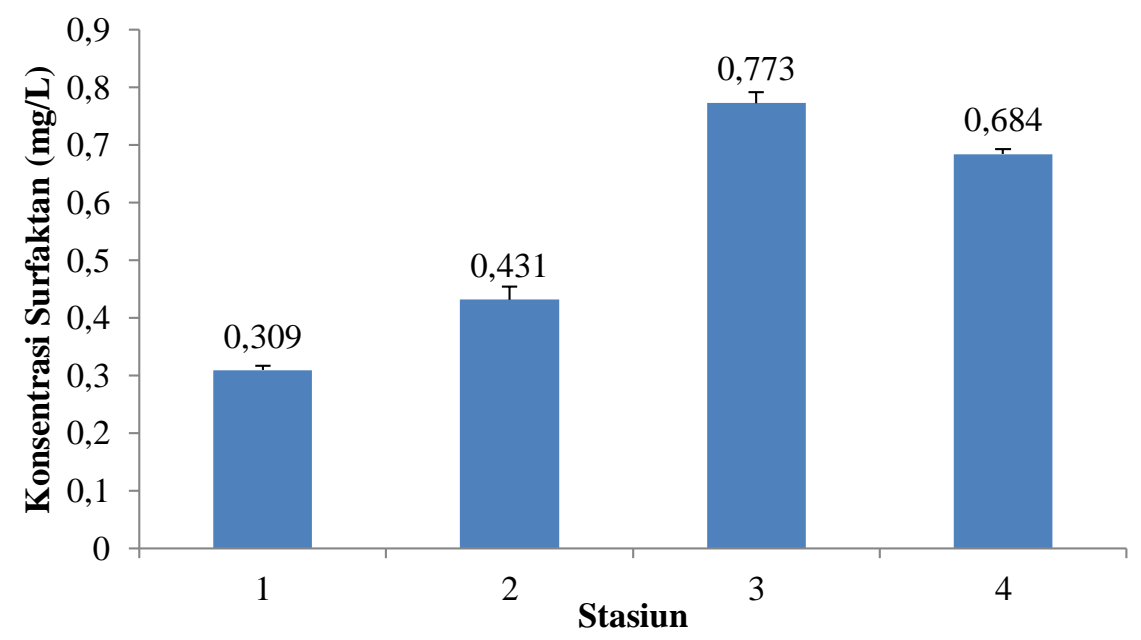

Gambar 1. Rata- rata konsentrasi Surfaktan Anionik di Perairan Bungus

\section{Jenis dan Kelimpahan Diatom}

Diatom merupakan komponen fitoplankton yang paling umum dijumpai di laut. Berdasarkan Gambar 1 dapat diketahui konsentrasi Surfaktan Anionik tertinggi ditemukan pada Stasiun 3 yaitu sebesar
0,773 mg/l, sedangkan konsentrasi surfaktan anionik terendah berada pada Stasiun 1 yaitu sebesar $0,309 \mathrm{mg} / \mathrm{L}$.

Adapun jenis diatom yang ditemukan terdapat pada Tabel 2.

Tabel 2. Jenis Diatom yang ditemukan

\begin{tabular}{|c|c|c|c|}
\hline Kelas & Ordo & Family & Spesies \\
\hline Bacillariophyceae & Pennales & $\begin{array}{l}\text { Fragilariaceae } \\
\\
\text { Nitzschiaceae } \\
\text { Tabellariaceae } \\
\text { Naviculaceae } \\
\text { Achnanthaceae } \\
\text { Aulacuseiraceae } \\
\text { Cocconeidaceae } \\
\text { Limcophoraceae }\end{array}$ & $\begin{array}{l}\text { Synedra sp. } \\
\text { Thallasiosira sp. } \\
\text { Fragilaria } \mathrm{sp} . \\
\text { Nitzschia } \mathrm{sp} . \\
\text { Grammatophora sp. } \\
\text { Navicula } \mathrm{sp} . \\
\text { Achnantes } \mathrm{sp} . \\
\text { Aulacuseira } \mathrm{sp} . \\
\text { Cocconeis } \mathrm{sp} . \\
\text { Limcophora } \mathrm{sp} .\end{array}$ \\
\hline & Centrales & $\begin{array}{l}\text { Leptocylindraceae } \\
\text { Bhidulphiaceae } \\
\text { Melosiraceae } \\
\text { Coscinodiscaceae } \\
\text { Oscillatoriaceae } \\
\text { Hemiaulaceae }\end{array}$ & $\begin{array}{l}\text { Leptocylindrus sp. } \\
\text { Guinardia } \mathrm{sp} . \\
\text { Isthmia } \mathrm{sp} . \\
\text { Ceratium } \mathrm{sp} . \\
\text { Melosira } \mathrm{sp} . \\
\text { Skeletonema } \mathrm{sp} . \\
\text { Tribonema } \mathrm{sp} . \\
\text { Lyngbya } \mathrm{sp} . \\
\text { Cerataulina } \mathrm{sp} . \\
\text { Hemiaulus } \mathrm{sp} .\end{array}$ \\
\hline & Bacillariales & Bacillariaceae & Bacillaria sp. \\
\hline
\end{tabular}


Sedangkan rata-rata kelimpahan diatom terdapat pada Gambar 2 rata- rata kelimpahan diatom tertinggi yang dibedakan menurut stasiun ditemukan pada stasiun 1 yaitu sebesar 81,4185 ind/L dan rata-rata kandungan diatom terendah ditemukan pada stasiun 3 yaitu sebesar $40,7047 \mathrm{ind} / \mathrm{L}$.

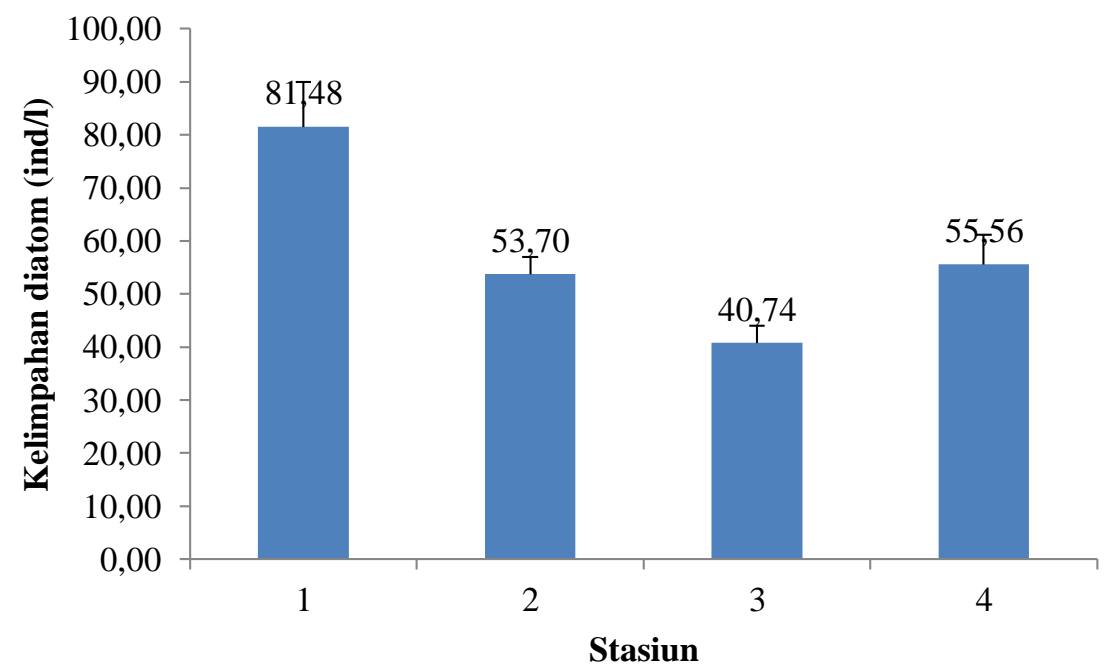

Gambar 2. Rata- rata Kelimpahan Diatom (ind/l)

\section{Hubungan Konsentrasi Surfaktan diatom di Perairan Bungus Padang Anionik dan Kelimpahan Diatom \\ Hubungan antara konsentrasi Sumatera Barat dapat dilihat pada Gambar surfaktan anionik dengan kelimpahan}

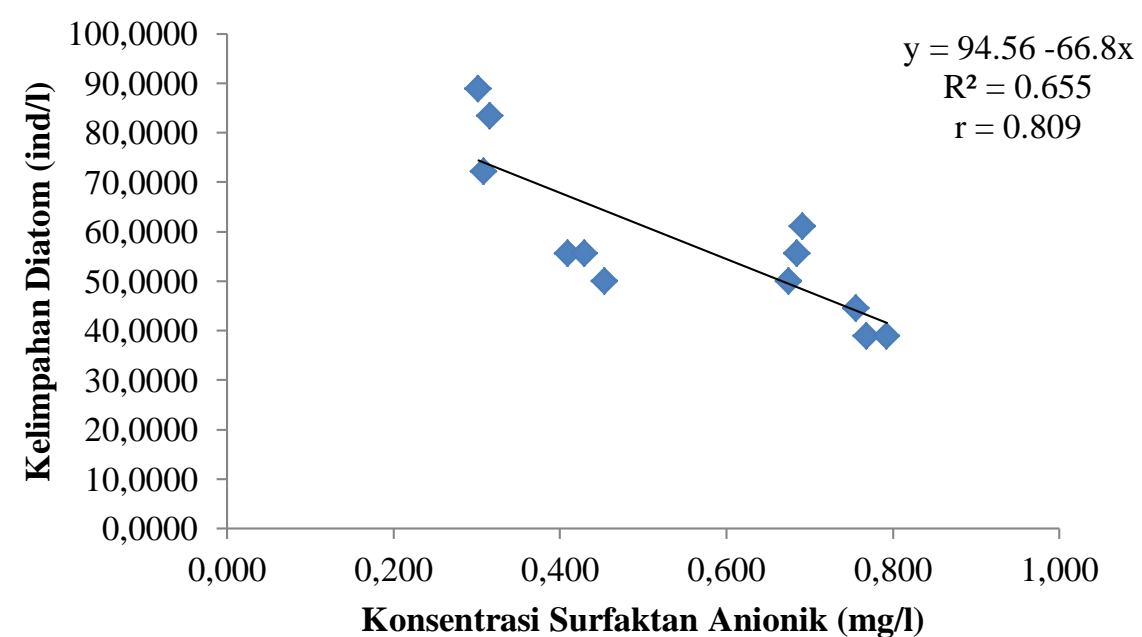

Gambar 3. Hubungan Konsentrasi Surfaktan Anionik dengan Kelimpahan Diatom

Berdasarkan dari hasil uji regresi linear sederhana, hubungan antara konsentrasi surfaktan anionik dengan kelimpahan diatom memiliki hubungan yang sangat kuat dengan persamaan matematis $\mathrm{y}=94.56-66.8 \mathrm{x}$ dengan koefisien determinasi $\left(\mathrm{R}^{2}\right)=0,655$ dan koefisien korelasi $\mathrm{r}=0,809$. Nilai $\mathrm{r}$ menyatakan hubungan sangat kuat dengan nilai yang negatif artinya dengan 
meningkatnya konsentrasi surfaktan pada perairan, maka kelimpahan diatom di perairan Bungus Padang, Sumatera Barat akan menurun.

Untuk mengetahui hubungan kualitas perairan dengan kelimpahan diatom dilakukan regresi berganda karena perlu dilakukan analisis terhadap kualitas perairan tersebut untuk melihat apakah kualitas perairan memiliki pengaruh terhadap kelimpahan diatom diperairan tersebut. Adapun hasil regresi linear yang terbentuk berdasarkan hasil perhitungan analisis regresi linear berganda adalah

$$
\begin{aligned}
Y= & a+b_{1} x_{1}+b_{2} x_{2}+b_{3} x_{3}+b_{4} x_{4}+b_{5} x_{5}+b_{6} x_{6} \\
Y= & 787,189-238,828_{X 1}-9,032_{X 2}- \\
& 6,185 \times 3+5,371_{X 4}+303,081_{X 5}-35,631_{X 6}
\end{aligned}
$$

Diatom diperairan Bungus Padang Sumatera Barat dapat dilihat pada Gambar dengan menggunakan uji linear sederhana berikut ini : Sesuai dengan penjelasan diatas maka kualitas perairan yang paling berdampak pada penurunan kelimpahan diatom adalah konsentrasi surfaktan 238.828, suhu sebesar -9.032, salinitas sebesar -6.185, kecerahan 303.081 dan kecepatan arus sebesar -35.631, dimana nilai surfaktan, suhu, salinitas dan kecepatan arus bernilai negatif artinya terdapat hubungan yang tidak searah antara kualitas perairan dengan kelimpahan diatom. Sedangkan nilai $\mathrm{pH}$ dan kecerahan memiliki hubungan yang searah dengan kelimpahan diatom di perairan. Berdasarkan persamaan tersebut dapat diperoleh angka $\mathrm{R}^{2}$ adalah 0,995 dan $\mathrm{r}$ 0,997. Hal ini menunjukkan terjadi hubungan yang sangat kuat antara kualitas perairan (surfaktan, suhu, salinitas, $\mathrm{pH}$, kecepatan arus, kecerahan) dengan kelimpahan diatom.

\section{Pembahasan \\ Konsentrasi Surfaktan Anionik}

Kawasan di Perairan Bungus Padang, Sumatera Barat terdapat berbagai aktivitas meliputi, kawasan pariwisata dan pemukiman penduduk juga terdapat Pelabuhan Teluk Bayur tidak jauh dari perairan ini. Aktivitas- aktivitas tersebut yang dapat mengakibatkan terjadinya pencemaran di perairan laut. Pencemaran air diakibatkan oleh masuknya bahan pencemar (polutan) yang dapat berupa gas, bahan-bahan terlarut dan partikulat. Pencemaran memasuki air dengan berbagai cara, misalnya melalui atmosfer, tanah, dan limpasan (run off) pertanian, limbah domestik dan perkotaan, pembuangan limbah industri (Effendi,2003). Salah satu hasil limbah yang dihasilkan yaitu limbah deterjen yang mengalir ke perairan dapat mengakibatkan terjadinya pencemaran lingkungan yang mana merupakan limbah yg paling banyak mengandung surfaktan. Hal ini tergantung pada jumlah limbah deterjen yang mengalir ke perairan, luas dan kondisi perairan serta dampak yang ditimbulkannya.

Berdasarkan hasil penelitian didapat nilai rata-rata konsentrasi surfaktan anionik pada stasiun 1 memiliki nilai konsentrasi surfaktan terendah dibandingkan dengan stasiun lainnya. Kawasan ini jauh dari aktivitas rumah tangga dan pelabuhan namun masih dipengaruhi aktivitas masyarakat, seperti lalu lalang kapal nelayan. Menurut Sur (2015) konsentrasi surfaktan di laut dapat berubah disebabkan oleh kecepatan arus, turbulensi dan pola pergerakan surfaktan anionik di perairan.

Menurut KEP/51/MENLH/ 2004 mengenai baku mutu air laut untuk biota laut menyatakan bahwa konsentrasi surfaktan di perairan adalah $1 \mathrm{mg} / \mathrm{l}$. Berdasarkan hal tersebut, maka dapat diketahui bahwa Perairan Bungus Padang belum tercemar oleh surfaktan sehingga masih bisa mendukung biota akuatik. 


\section{Kelimpahan Diatom}

Diatom merupakan organisme yang digunakan sebagai bioindikator pada kualitas perairan dari organisme/ kelompok organisme lainnya. Keberadaan diatom di suatu perairan sangat penting, karena merupakan produsen primer di perairan, pakan alami yang disukai ikan, udang, moluska, bivalva sehingga penyebarannya dipengaruhi oleh keberadaan pemangsa terutama ikan (Anshorullah, 2008).

Berdasarkan hasil penelitian jumlah kelimpahan diatom tertinggi terdapat pada Stasiun 1 yaitu 81,4185 ind/L. Hal tersebut disebabkan Stasiun 1 berada jauh pada daerah pemukiman penduduk dan jauh dari kegiatan industri sehingga tidak adanya kegiatan rumah tangga yang dapat menghasilkan limbah bahan organik yang dapat mempengaruhi kelimpahan diatom. Sedangkan untuk kelimpahan diatom yang terendah ditemukan pada Stasiun 3 yaitu $40.7407 \mathrm{ind} / \mathrm{L}$. Stasiun ini dekat dengan pembuangan limbah, aktivitas rumah tangga . Pada penelitian ini diatom yang mendominasi adalah spesies Nitzchia sp dan Leptocylindrus sp, spesies ini mendominasi hampir di setiap stasiun. Arinardi (1997) menyatakan bahwa Nitzchia sp sangat resisten pada perairan yang kaya akan bahan organik. Hal ini dikarenakan Nitzchia sp mampu memanfaatkan secara optimal kondisi lingkungan yang ada dan nutrient di dalamnya, Nitzchia sp merupakan generasi yang memiliki toleransi tinggi terhadap perubahan kondisi lingkungan perairan.

Suryanto (2011) menyatakan bahwa ada 3 pembagian perairan berdasarkan kelimpahan fitoplankton yaitu perairan oligotrofik merupakan perairan yang tingkat kesuburannya rendah dengah kelimpahan fitoplankton berkisar antara 0$2.000 \mathrm{ind} / \mathrm{L}$, perairan mesotrofik merupakan perairan yang tingkat kesuburunnya sedang dengan tingkat kelimpahan fitoplankton berkisar antar 2.000-15.000 ind/L, dan perairan eutrofik merupakan perairan yang tingkat kesuburannya sedang dengan kelimpahan fitoplankton berkisar antara $>15.000 \mathrm{ind} / \mathrm{L}$. Berdasarkan pengklasifikasian tersebut maka Perairan Bungus mempunyai tingkat kesuburan yang rendah karena kisarannya adalah 40,7407 - 81,4815 ind/L.

Haumahu (2004), menyatakan distribusi dan sebaran fitoplankton tidak merata di setiap perairan karena dipengaruhi oleh faktor-faktor fisika dan kimia perairan seperti angin, arus dan kandungan nutrient. Perubahan suhu permukaan laut dipengaruhi oleh jumlah panas yang diterima dari matahari dan bertambahnya kedalaman.

\section{Surfaktan}

Berdasarkan persamaan regresi dapat dikatakan terdapat hubungan yang negatif antara variabel surfaktan terhadap kelimpahan diatom dengan koefisien regresi variabel sebesar -238.828 yang mana semakin tinggi nilai surfaktan maka kelimpahan diatom akan semakin menurun.

Surfaktan adalah zat yang sangat sulit terdegradasi, sehingga ketika berada di perairan surfaktan masih berada di perairan berbentuk partikel yang dapat mempengaruhi kecerahan di perairan tersebut dan mengakibatkan phytoplankton atau diatom terganggu pertumbuhannya. Berdasarkan Tabel. 4 konsentrasi surfaktan tertinggi berada pada stasiun 3 sebesar $0,773 \mathrm{mg} / \mathrm{l}$ yang merupakan stasiun dengan nilai kelimpahan diatom terendah yaitu 40,7407 ind/L.

\section{Kecerahan}

Kecerahan merupakan faktor utama yang mengontrol pertumbuhan fitoplankton. Kecerahan adalah perkiraan kemampuan penetrasi sinar matahari kedalam perairan. Tinggi rendahnya kecerahan akan mempengaruhi kegiatan fotosintesis dan produktifitas perairan atau kesuburan perairan. Kecerahan pada suatu perairan dipengaruhi oleh zat-zat yang 
terlarut dalam perairan, sehingga berhubungan dengan penetrasi sinar matahari. Semakin tinggi kecerahan, maka intensitas cahaya yang masuk ke dalam suatu perairan semakin besar (Nybakken,1988 dalam Zahidin, 2008).

\section{Suhu}

Berdasarkan persamaan regresi dapat dikatakan bahwa terdapat hubungan yang negatif antara variabel suhu terhadap kelimpahan diatom dengan koefisien regresi variabel sebesar -9.032 dan yang mana semakin tinggi suhu maka kelimpahan diatom akan semakin rendah. Suhu air di Perairan Bungus berkisar antara 30-31, perairan ini tergolong dalam perairan baik.

Berdasarkan hasil penelitian diketahui bahwa suhu tertinggi berada pada stasiun 2 dan 3 yaitu $31^{\circ} \mathrm{C}$ dimana stasiun 3 merupakan stasiun dengan nilai kelimpahan diatom terkecil yaitu 40,7407 ind/l.

Hubungan konsentrasi surfaktan dengan suhu sepertinya tidak terlalu signifikan, hal ini karena nilai konsentrasi surfaktan tertinggi berada pada stasiun 3 dan nilai suhu tertinggi terdapat pada stasiun 2 dan 3 dimana stasiun 2 adalah stasiun dengan nilai surfaktan terendah setelah stasiun 1 .

\section{Salinitas}

Berdasarkan persamaan regresi dapat dikatakan bahwa terdapat hubungan positif antara variabel salinitas terhadap kelimpahan diatom dengan koefisien regresi variabel sebesar -6.185 yang mana semakin tinggi salinitas maka kelimpahan diatom akan semakin rendah. Pengukuran Salinitas di Perairan Bungus diperoleh nilai antara 28-29 ppt.

Menurut Nontji (2008), sebaran salinitas di laut dipengaruhi oleh berbagai faktor yaitu sirkulasi air, penguapan, curah hujan dan aliran sungai. Namun pada Tabel 1. Nilai salinitas terendah berada pada stasiun 4 yaitu 28 (ppt) dimana pada stasiun ini kelimpahan diatom adalah tertinggi kedua setelah stasiun 1 bernilai 55,5556 ind/l. Sedangkan salinitas sepertinya tidak memiliki hubungan yang signifikan dengan konsentrasi surfaktan. Sama seperti diatom, stasiun 4 juga merupakan stasiun dengan nilai konsentrasi surfaktan tertinggi kedua yaitu $0,684 \mathrm{mg} / \mathrm{l}$

\section{pH}

Berdasarkan persamaan regresi dapat dikatakan bahwa terdapat hubungan positif antara variabel $\mathrm{pH}$ terhadap kelimpahan diatom dengan koefisien regresi variabel sebesar 5.371 yang mana semakin tinggi pH maka kelimpahan diatom akan semakin tinggi. Variasi $\mathrm{pH}$ dapat mempengaruhi metabolisme dan pertumbuhan fitoplankton dalam beberapa hal, antara lain mengubah ketersediaan nutrien dan dapat mempengaruhi fisiologis sel. Nilai derajat keasaman $(\mathrm{pH})$ di Perairan Bungus berkisar antar 7 - 8. Koko (2009) menyatakan bahwa kisaran $\mathrm{pH}$ yang baik untuk pertumbuhan fitoplankton adalah 6,0 - 9,5. pH yang kurang dari 6,0 menyebabkan fitoplankton tidak dapat hidup dengan baik dan pada keadaan dimana $\mathrm{pH}$ besar dari 9,5 maka perairan tidak produktif lagi. Namun berdasarkan hasil pengukuran kualitas perairan (Tabel. 1) Surfaktan tidak berpengaruh besar terhadap $\mathrm{pH}$ di perairan ini meskipun nilai $\mathrm{pH}$ tertinggi berada pada stasiun 3 yang mana juga merupakan stasiun dengan nilai surfaktan tertinggi juga.

\section{Kecepatan Arus}

Berdasarkan hasil perhitungan regresi diketahui adanya hubungan negatif antara variabel Kecepatan arus terhadap kelimpahan diatom Koefisien regresi kecepatan arus -35.631 maka apabila nilai kecepatan arus meningkat kelimpahan diatom akan semakin rendah.Sebaran diatom sangat dipengaruhi arus perairan karena organisme ini bergerak mengikuti arah arus dan tidak cukup kuat untuk melawan gerakan air yang terlalu besar. 
Kecepatan arus dibedakan menjadi empat kategori, yaitu : 1) kecepatan arus 0 $25 \mathrm{~m} /$ detik berarus lambat, 2) kecepatan arus $25-50 \mathrm{~m} /$ detik berarus sedang, 3) kecepatan arus $50-100 \mathrm{~m} /$ detik berarus cepat, 4) kecepatan arus >100 m/detik berarus sangat cepat (Harahap, 2004). Perairan Bungus berarus lambat berkisar antara $0,7-0,8 \mathrm{~m} /$ detik

Berdasarkan hasil pengukuran kualitas perairan (Tabel. 1) Kecepatan arus tertinggi berada pada stasiun 3 yaitu 0,8 $\mathrm{m} /$ det yang mana stasiun tersebut merupakan stasiun dengan nilai surfaktan paling tinggi yaitu $0,773 \mathrm{mg} / \mathrm{l}$. Namun menurut Sur (2015) konsentrasi surfaktan di laut dapat berubah disebabkan oleh kecepatan arus, turbulensi dan pola pergerakan surfaktan anionik di perairan. Hal ini mungkin saja terjadi akibat stasiun 3 merupakan kawasan dekat penduduk yang mana banyak menghasilkan buangan berupa limbah rumah tangga

\section{KESIMPULAN DAN SARAN}

1. Konsentrasi surfaktan anionik di Perairan Bungus berkisar 0,309 mg/l - 0,773 mg/l, Sedangkan kelimpahan diatom berkisar 40,7407 - 81,4815 ind/l. Kelimpahan diatom di Perairan Bungus memiliki tingkat kesuburan yang rendah dengan kisaran 0 - 2000 ind/L.

2. Konsentrasi surfaktan anionik dan kelimpahan diatom di perairan
Bungus memiliki persamaan regresi $\mathrm{Y}=94,56-66,8 \mathrm{x}$ dengan nilai $\mathrm{r}$ sebesar 0,809 yang berarti hubungan konsentrasi surfaktan dengan kelimpahan diatom adalah sangat kuat ke arah yang negatif.

3. Sedangkan hubungan Faktor fisika kimia perairan dengan kelimpahan diatom memiliki nilai persamaan sebagai berikut $\mathrm{Y}=787,189$ $238,828_{\mathrm{X} 1}-9,032_{\mathrm{X} 2}-6,185_{\mathrm{X} 3}+5,371_{\mathrm{X} 4}$ $+303,081_{X 5}-35,631_{X 6}$ dengan nilai $\mathrm{R}^{2}$ adalah 0,995 dan $r \quad 0,997$. Nilai korelasi $r$ tertinggi terdapat pada parameter kecerahan dan surfaktan yaitu sebesar 303,081 dan -238,189 dimana semakin tinggi kecerahan maka kelimpahan diatom akan meningkat dan semakin tinggi konsentrasi surfaktan maka kelimpahan diatom semakin menurun.

4. Menurut KEP/51/MENLH/ 2004 konsentrasi surfaktan di perairan adalah $1 \mathrm{mg} / \mathrm{l}$. Berdasarkan hal tersebut maka konsentrasi surfaktan anionik di Perairan Bungus dinyatakan masih dalam batas normal dan masih mendukung untuk kehidupan biota. Konsentrasi surfaktan anionik dengan kelimpahan diatom diperoleh hubungan yang signifikan.

\section{DAFTAR PUSTAKA}

1. Anshorullah, A. (2008). Distribusi Diatom Planktonik pada Musim yang Berbeda di Perairan Waduk Wadaslintang Wonosobo. FMIPA. Universitas Brawijaya dengan Perum Jasa Tirta 1 (PJT 1) Malang.

2. Effendi, H. (2003). Telaah Kualitas Air. (p.11). Yogyakarta: Kanisius.

3. Haumahu, S. (2004). Distribusi Spatial Fitoplankton di Teluk Ambon Bagian Dalam Ichtyos, Jurnal Hasil Penelitian. Ilmu- ilmu Perikanan dan Kelautan, Volume 3(2).

4. Kamiswari, R. (2013). Pengaruh Pemberian Detergen terhadap Mortalitas Ikan Platty sp. Lentera Bio, Volume 2(1), Pages 139-142

5. Koko, A. (2009). Struktur Komunitas Fitoplankton di Muara Sungai Air Bengkulu, Kota Bengkulu. Skripsi. Fakultas Perikanan dan Ilmu Kelautan. Universitas Riau. Pekanbaru. (p. 78) 
6. Nontji, A. (2002). Laut Nusantara. Cetakan 3. Penerbit Djambatan. Jakarta.

7. Nybakken. J.W. (1992). Biologi Laut: Suatu Pendekatan Ekologis. Alih Bahasa Eidman dkk.

8. Pusat Riset Wilayah Laut dan Sumberdaya Non Hayati. (2006). Laporan Akhir Inventarisasi Sumberdaya Kelautan Teluk Bungus. Jakarta: Tim Pelaksana Kegiatan PRWLSDNH, BRKP, DKP.

9. Siregar, S.H, A. Mulyadi, dan O.J. Hasibuan. (2008). Struktur Diatom Epilitik (Bacillariophyceae) pada Lambung Kapal di Perairan Dumai Provinsi Riau. Journal of environmental Science, Volume 2(2), Pages 1978-5283

10. Suryanto, A.M. (2011). Kelimpahan dan Komposisi Fitoplankton di Waduk Selorejo Kecamatan Ngantang Kabupaten Malang. Fakultas Perikanan dan Ilmu Kelautan Universitas Brawijaya, Jurnal Kelautan. Volume 4(2)

11. Terangna., Nana, Rahayu, dan Sukmawati. (1989). Peranan Mikroorganisme Aerob pada Penguraian Detergen dalam Air, JLP No.13 Th.4-KW1, Jakarta 